\title{
A Post-Colonial Analysis on Modern Novels
}

\author{
Iskandar Mohammed Abbas, Zaidah Bt Zainal, Saad NajimAL-Khafaji
}

\begin{abstract}
The aim of this paper is to highlight that Post-Colonial writers in English novels pay more attention on common themes such as emigration, independence struggles, allegiance, national identity, and childhood. This paper speaks about the heart of the darkness by joseph Conrad and a passage to India by E.M Forster and how the themes of these two novels deal with postcolonialism and the relationship between both colonizer and the colonized. It explains the world of colony and how it describes a group of people leaving their native country to settle in a new geographical location subject to, and how post-colonial theory is built in large part around the concept of otherness with its associated problems including doublings of identity, values and meaning of the colonising culture and resistance. The study tries to show how the apparent holy mission of the colonisers led to their own loss. It also gives how the coloniser's characters are caught between inner moral pressure conflicts and social demands. Man, in a colonised country is also torn between the uncertain world and his dissatisfying home. The study proclaims how a personal dilemma is a true reflection of the moral hypocrisy. The study concludes by depicting how hypocrisy and moral duality lead the colonizer to lose their identity as well as explaining one of the problems associated with colonizer theory, the attempt to maintain a national identity.
\end{abstract}

Keywords: Identity, Post-colonialism, Otherness, Moral hypocrisy, The novelist Joseph Conrad, The novelist E.M Forster.

\section{INTRODUCTION}

Britain's former colonies in Africa, India and the Caribbean form the basis of pre-colonial literature with many of the writers focusing on common themes including national identity, struggle for independence, allegiance, childhood etc. Colony is a term used to refer to "a group of people who leave their native country to form a new land in a settlement subject to, or connected with, parent nation." (www.dictionary.com $>$ browse >colonies). According to Margaret Khon, who wrote about the Post-Colonial theory, Colony "is the practice of domination which involves the subjugation of one people to another" (http://platostandford.edu>entries $>$ margaretkhon). On the other hand, colonization is a process where a central system of power rules the surrounding land and its components. The word (colony) was coined from the Latin word, 'Colere' meaning 'to inhabit' (Ferro, 24). Generally, colonialism therefore, is considered as a system of domination or authority established to control a set of individuals or groups over a given territory or behaviour of those individuals or groups. It is also considered a form of exploitation, with emphasis on economic variables that lead to culture change. The idea of domination is closely related to the concept of

Revised Manuscript Received on October 15, 2019.

Iskandar Mohammed Abbas, Ministry of Educations, Iraq. Malaysia, 81310, Johor Bahru, Malaysia.

Saad NajimAL-Khafaji, University of Bagdad ,Iraq.
Zaidah Bt Zainalb, bLanguage Academy, Universiti Teknologi

power (Maunier, 1949). Cooper (1997), in his book Tensions of Empire: Colonial Cultures in Bourgeois World, declares that; Post-Colonialism as a term is derived from Colonialism and Imperialism. In other words, it is the colonial mind that considers the colonized natives as the "Other" and crushes over the years their voice as inferior (Cooper, 1997).

Post-Colonial theory is majorly built around the concept of "otherness". Some of the problems associated with the concept of otherness include doubling of identity, values and meaning of the colonising culture and resistance. Accordingly, post-colonialism can be defined as "a body of writing that attempts to shift the dominant ways in which the relations between Western and non-Western people are depicted". Late 19th century European possession of Asia and Africa experienced a sudden invasion of foreign influence and those "mother countries" received a mutual impact from their colonies. A mass parallel lists with separate headings of "Imperial Impact" and "Domestic influence" to demonstrate the mutual effects of European expansionism (Jervis, 1999).

Drawing on recent theoretical developments in postcolonial research, one can examine studies that are related to it like, hybrid epistemology, a study that includes the mixture between the coloniser and the colonized and their mutual effects on each other. One of the central ideas of Bhabha (1994), an Indian English scholar, a critical theorist and one of the most important figures in contemporary Post-Colonial studies, is that of "hybridisation", which describes the advent of new cultural norms resulting from the multicultural scenario brought about by colonialism. Rather than view colonialism something locked in history, Bhabha was abed to show how these histories and cultures recurrently interrupt the present, with the expectation of transforming our understanding of cross-cultural relations. His work adopted the methodology of post-structuralism to transform the study of colonialism to colonial texts (Bhabha, 1994). Accordingly, Orientalism is an ideology which talks about the negative view of the Westerns toward the eastern Asian as regard themselves as Superior while the others as Inferior.

\section{HISTORICAL STUDY}

Historically, nations such as Greece and Phoenicia, establish colonies to farm, in uninhabited land. The Romans also colonized in the ancient times, some large parts like Western Europe, North Africa and West Asia. The Romans regarded the nations they conquered as uncivilised people and enslaved them.

For example, the Romans founded 'Londinium' as the British capital city of London (Furnivall, 1948). According to Western historical tradition, colonial phenomenon is placed or considered to be the time of

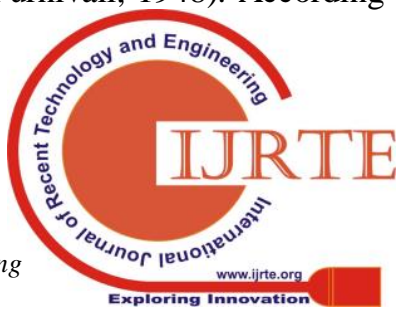




\section{A Post-Colonial Analysis on Modern Novels}

great discoveries. The Colonial adventure during the 15th century enabled Spanish Empire to stretch across different continents, while England and France started during 16th and 17 th century to establish their own overseas empires. For instance, historical tradition has it on record that the expansion of those countries is linked to the discovery of the distant lands in places like the West Indies. Decolonisation, derived from colonise, is a new term that appeared during 18th and 19th century, it was termed as the era of imperialism (Hobson, 1965).

Hack (2008), in his International Encyclopaedia of the Social Science; posited that, Decolonisation is the reversal or undoing of colonialism. A scenario where a nation under colonization establishes and regains its right from the domination imposed on them by the masters. Decolonisation does not only refer to the removal of the coloniser's domination within the geographical space, but it also refers to the intellectual decolonisation from the colonisers' ideas that made the colonized feel inferior and unjust treatments (Hack, 2008). The distinction between Colonialism and Imperialism is too close and confusing sometimes. For example, despite the greatness of British's empire, America feels superior in a moral sense to Britain. Moreover, America has dominated Middle American countries not only politically but also economically. Afro-Americans today declare that they are victims of imperialism and they suffer racism. Furthermore, the Third World Countries have sensed the evils of colonialism. Many scholars failed to provide definitions because they feel that the two terms, Imperialism and Colonialism are identical. Since a large portion of the literature on Colonialism is found in the humanities, this point is especially important Koebner \& Schmidt, 1964). Post-Colonialism is the literary theory that shows how the Imperialists, or the Colonialists put their principles in action as manifested through literary texts.

The reasons for Colonization are either religious, love of adventure, thirst for wealth and struggle for an empire. Religious colonization is manifested through the relationship between the Arab world and the West. The Arabs believe crusades were the basis for European expansion, which is considered the first expression of 'imperialism'. By contrast, the westerns view the Crusades as an attempt to prevent Islam from conquering the Christian country. Arab Islam would manage to unify the Mediterranean world after being fragmented for years because of the Roman Empire and afterwards the Barbarians occupations. Islam started to expand in the east and west. Byzantium for Muslims originally represents an Islamic state that was dominated by Christianity. The following centuries witnessed the break-up of the Arab Empire because of the internal theological and dynastic conflicts. As a result, Christians succeeded to liberate themselves (Schumpeter, 1951). In addition, the Empire of the Franks managed to invade the Islamic lands in (A.D. 1086). With the coming of the Spanish Philip II, three centuries later, Islam was defeated by the Christians at the battle of Lepanto in 1571. The Arab Muslims were the Arab Empire was destroyed completely due to the Turkish and then the westerns, which renewed the attack during the time of Imperialism. Actually, the Muslim Empire never had been as powerful as it was during the time of Suleiman; the longest-reigning Sultan of the Ottoman Empire 1520-1566.
Accordingly, to be able to trade with India and China, christians started to search for ways to bridge the relations with the Ottoman's who were occupying the Arabs (Toynbee, 1951).

Many writers wrote during colonization, and such literature on colonization appear to have no end and understanding of colonialism. This has been one of man's major obsessions. The changing nature and morality of colonist contributes to our lack of understanding. Also, with prominence to economic variables, colonialism has also been a form of exploitation, as in the Marxist-Leninist literature. One cannot neglect the fact that culture changes with colonial dominance (Maunier, 13-14).

\section{EURopean COLONIALISM IN NOVELS}

\section{A. Heart of Darkness (1899) by Joseph Conrad}

Joseph Conrad in the Heart of Darkness (1899) explores the issues surrounding imperialism in complicated ways. It is set in Congo, in the heart of Africa. Marlow faced series of near-slavery, torture and cruelty as travels from the outer station through the central station up the river and finally to the inner station. At the very least, the incidental scenery of the book suggests severe scenes blamed on colonial boldness. Marlow's adventures were motivated by the essential hypocrisy often used to justify imperialism. The companies have men who work for them and are bold in describing their work as "trade," and their ill-handling of native Africans as civilization projects. A protagonist, Kurtz, was however opened about the fact that they took ivory coast by force and never by trade. He went further to use the terms, "suppression" and "extermination" in describing his own treatment of the natives stressing the fact that he ruled through violence and terrorisation. Nonetheless, his stubborn honesty was the bane of his downfall, as his success threatens to expose the evil practices behind European activity in Africa. (https://www.bachelorandmaster.com/.../heart-of-darkness-. html.).

Selecting Joseph Conrad as a novelist that represents post-colonial literature, is a good choice for Conrad, who is considered one of the best who wrote about post-colonial themes. An essay that discusses Conrad's views declares that; "This is a running theme through most Conrad's books. As a sailor he learned that to survive, every crewman did the job he was assigned, and that the survival of the ship, and therefore the community, depended on each man doing his duty" (Bartley, Views on Colonialism). His novel Heart of Darkness (1902) is an autobiographical fiction that deals with identity crisis, imperialism, and race relations; which are the major themes that are related to post-colonial theory.

"The Heart of Darkness can be read as a political critique of western imperialism as exercised by the Belgians, who more or less raped the Congo of its resources while brutalizing the country's people and making them slaves of unbridled political avarice" (Bartley, Views on Colonialism)

Furthermore, the novel has been studied and described as a metaphorical journey into the human soul, or as a political journey in the dark heart of European colonization, or 
even as a nightmare journey of horror. Such studies related to the novel are different from the focus of the present study which aims at shedding more light on white men than the colonized. Harold Bloom, the American literary critic, has analyzed many literary works saying that Conrad's Heart of Darkness is one of the most studied novels in universities and colleges. This might be due to Conrad's uniqueness and ambiguity of his style which makes his book so fascinating and challenging (Royle, p.41). In another study, Albert J. Guerard, a notable critic wrote "The Journey Within" in Heart of Darkness, in which he deals with Conrad's personal story, as an autobiography. It presents the story not just as geographical exploring but an inner exploring for the major character. The novel is considered according to Guerard, as a record of things that have been seen and done, by doing so, Conrad is moralising indirectly the cold-war propaganda. (p.6)

Europe is interested in Africa for many reasons. The Continent is a rich land with natural resources; gold, crude oil, ivory, spices...etc. So, calling Africa the "Dark Continent," laid the right kind of challenge for their interest. The richness and mystery of Africa particularly interest Africa's early explorers. Following, the establishment of colonial rule, a very strong working relationship was forged between the colonial authorities and the missionaries. The missionaries staffed and ran most of the schools with the main motive of using education to enlighten Africans to meet the limited need for semiskilled labor. Culturally, those European people were arrogant, they felt they are superior, and anyone who is different was regarded as culturally inferior to them. So, they believed they have a duty to 'uplift' or 'civilize' those Africans.

\section{B. A Passage to India (1924) by E.M. Forster}

A Passage to India (1924), encapsulates the presentation of the question on whether there is possibility of true friendship between an Indian and an Englishman, within the ambit of British colonialism. To have more insights by exploring the political control of the Britain, Forster capitalizes on these questions as an outline although on a more personal level, through the friendship between Aziz and Fielding. At its beginning, Aziz disrespected the English, and even completely ignored them.

As time passes by, Aziz began to feel the possibility of friendship with Fielding. They later represented a positive model of liberal humanism making Forster to suggest that British rule could be successful and respectful in India, if only other English and Indians would treat each other just as Fielding and Aziz do - as worthy individuals who connect through honesty, intelligence, and morals (www.rottentomatoes.com/m/passage_to_india.). This relation is seen against many other relationships in which the English failed to impose their culture on Indian people. The main character in this novel is Scobie, during World war II, he was a police officer in a colony in the British West Africa. He was married to an intellectual woman, Louise with whom he had one daughter named Catherine, who died many years ago.

E.M. Foster's novels are so popular, that one cannot deny how many studies have dealt with his books in general and with A Passage to India in particular. Haider Mohammed
Mezaal, A Professor from the University of Khartoum wrote: A Passage to India: A Critique of Imperialism, in which he sheds light on E. M. Forster's attack against British imperialism in colonial India. The study claims that obtaining an official position in the imperialistic government makes Anglo-Indians start making racial preconceptions about the Indians. This attitude, for sure, damages the chance of forming a friendship between the Indians and the British. Ahmad Jasim Mohammad's Symbolism as a Modernist Feature in a Passage to India, the study discusses the employment of symbols in the novel in a way that gives different meanings. It is through symbols that the author gives us different interpretations to the reader by showing meanings through images. Symbols like echo, Mosque, cave, green bird, wasp...etc. Forster personifies nature also to highlight the mystery of India and the failure of the rational British mind to comprehend it. (p.55)

The novelist here depicts one of the memorable scenes in the novel is that of the cave. The inability of understanding the echo in the caves is yet another cultural barrier; it stops crossing the bridge between the East and the West. Because of the difficulties to establish a friendship with the British, those Indians start fighting to gain their freedom. (Mezaal, 56). Another study is conducted by Vipin Behari Goyal, The Cave Theory" in "A Passage to India". This study also sheds light on the psychological importance of the cave scene. A passage to India is a novel about two British ladies who came to India to understand India and Indians. Like all other Europeans and most of the Westerners, they are disappointed and suffer cultural shock. (Goyal, 77).

The many studies that dealt with A Passage to India to India have so far dealt with the novel from a linguistic point of views such as language and the role of symbolism or from a Post-Colonial perspective shedding light mainly on the dilemma of the Indian subjects. Present studies are focused on the negative effects of colonialism on the colonizers themselves by adopting the same Post - Colonial critical theory.

\section{CONCLUSION}

To conclude, the crisis of identity is one of the most important problems in post - colonial studies, and it is a significant issue that appeared in the newly independent nations. Different perceptions are depicted by the novelists about that issue. In general, no matter how many perspectives there are, one thing for sure is that after any colonized culture, they suffer from keeping their old original identity.

Nothing remains the same and everything is affected by the colonizers, and the colonized are confused about what their real identity is. The feeling of not belonging to the past or present is what creates this crisis of identity.

Studying those two novels from post-colonial point of views is important because these novels though were analyzed before, but they were never analyzed from colonialism standpoint. Studying them from this perspective gives the reader a new image and picture of the novel that has not been seen before. And of course, to show the effect of colonialism on the countries, and the importance of

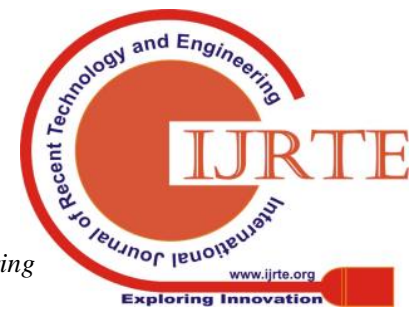




\section{A Post-Colonial Analysis on Modern Novels}

searching for one's identity in a time that it faces difficulties is what shapes the works. Though, there would be a reference to the colonized people, yet the main focus of the present study would be on the colonizers or the white men who assumingly come to guide those inferior people only to end in a loss.

\section{REFERENCES}

1. Bartleby. Joseph Conrads' Views on Colonialism. New York: Barnes \& Noble Education, Inc. 2018. https://www.bartleby.com/essay/Joseph-Conrads-Views-On-Colonial ism-P3ENFRZTJ.

2. Bhabha, Homi K. The Location of Culture. London: Routledge, 1994

3. Cooper, Fredrick \& Ann Laura Stoler. Tensions of Empire: Colonial Cultures in Bourgeois World. Berkeley, CA: University Califorina Press, 1997.

4. Ferro, Marc. Colonization: A Global History. New York: Routledge publication, 1997

5. Furnivall, J.S. Colonial Policy and Practice. London: Cambridge University Press, 1948.

6. Goyal, Vipin Behari. The Cave Theory" in "A Passage to India". India: Jai Narain Vyas University press, 2016.

7. Guerard, Albert J. "The Journey Within" in Joseph Conrad: Heart of Darkness. Massachusessts: HarvardUniversity Press, 1966.

8. Hack, Karl (2008). International Encyclopedia of the Social Sciences. Detroit: Macmillan Reference USA. pp. 255-257.

9. Hobson, J.A. Imperialism: A Study. London: G.Allen and Unwin, 1902

10. https://www.bachelorandmaster.com/.../heart-of-darkness-.html

11. Jervis, J. Transgressing the Modern, Exploration of the Otherness. London: Blackwell, 1999.

12. Koebner, R. and H. O. Schmidt. Imperialism: The Story and Significant of a political Word, 1840-1960. Cambridge: Cambridge University Press, 1964

13. Maunier, R. The Society of Colonies. Vol. 1 London: Routledge and Kegan Paul, 1949.

14. Mezaal, H. M. A Passage to India: A Critique of Imperialism. Sudan: University of Khartoum press, 2018.

15. Mohammad, A. J. Symbolism as a Modernist Feature in a Passage to India. in IOSR Journal of Engineering (IOSRJEN) Iraq: Cihan University press, 2015.

16. Royle, Nicholas. 'Reading Joseph Conrad: Episodes from the Coast' in Mosaic: An Interdisciplinary Critical Journal (March 2014).

17. Toynbee, A. J. A Study of History. New York: A.M. Kelley, Vol.7, 1951.

18. http://platostandford.edu $>$ entries $>$ margaretkhon)

19. www.dictionary.com $>$ browse $>$ colonies

20. www.rottentomatoes.com $/ \mathrm{m} /$ passage_to_india.

\section{AUTHORS PROFILE}

I am Iskandar Mohammed Abbas, I am affiliated with Ministry of Educations, Iraq.my area of research is social science and history.

My name is Zaidah Bt Zainalb, I am affiliated with bLanguage Academy, Universiti Teknologi Malaysia, 81310, Johor Bahru, Malaysia.

My name is Saad NajimAL-Khafaji, I am associated with University of Bagdad ,Iraq. My area of interest is social sciences.my area of interest is social sciences 